\title{
A SUBSTITUTE FOR PROSE COMPOSITION IN THE TEACHING OF LATIN
}

\author{
WALDO E. SWEET \\ University of Michigan
}

For many years one of the chief weapons in the arsenal of the Latin teacher was Prose Composition, the turning of set English sentences into Latin. In recent years, however, the technique has fallen into disfavor in many quarters. Most of the textbooks use the Reading Approach, although they still include English sentences for the teachers that want to use them.

When questioned about methods, most teachers, aware of the unfashionable state of Prose Composition, claim to put little emphasis on this activity, but questioning often reveals that this actually amounts to a third or a half of the total time.

The common argument against Prose Composition runs somewhat as follows: Although writing Latin was a valid goal in the Middle Ages and the Renaissance, when an educated man had a real need for this skill to participate in the activities of state, church, law, science, or scholarship, the modern objective is reading. Prose composition requires a great deal of active learning of forms and vocabulary and consumes time which might better be spent in actual reading. Lastly, say the critics, the activity is dull and unrewarding to the student.

Almost all the modern texts, therefore, stress the reading of graded material which proceeds smoothly from "made" Latin to an adapted author, usually Caesar, in which the greater difficulties have been removed. Students who continue Latin beyond the second year of high school advance to authors that have not been adapted, traditionally Cicero and Vergil.

Many experienced teachers, however, believe that in practice these carefully graded texts do not provide the smooth transition which they promise. Through trial and error they have proved, to their own satisfaction at least, that their students do not do as well without Prose Composition; and in spite of the theoretical objections given above they continue to use this technique. Structural linguistics seems to throw considerable light upon this controversy. 
The Reading Method, at least as it actually operates at the present, is deficient in one vital respect: the easy Latin does not demonstrate the essential features of Latin. First of all, it is written in a word order that is essentially English, thus permitting the students to comprehend the syntax by English signals of position rather than by Latin signals of inflection. The students will interpret puer as subject in Puer puellam speclat not because of its nominative form but because in their experience the subject, if expressed, always precedes the object. They have never seen such a sentence as Puellam spectat puer. The verb is identified as a verb not because of its morphological characteristics but because it regularly comes last in declarative sentences, first in questions or commands. In other words, in these beginning texts, word order is most emphatically a grammatical signal, although it is not in real Latin. With their background of English, American students rely upon these pseudo-signals of position and ignore the real signals of the inflectional endings.

Vocabulary is similarly oversimplified. The pupils have no chance to observe that words are areas of meaning and not points of meaning because in this material vocabulary items are used in such contexts that they may consistently be translated by one English meaning. Gerō, for example, almost invariably patterns with bellum to mean wage, ignoring the dozens of other equally common meanings.

It is a commonplace among those who have applied linguistics to practical language teaching that fundamental points of structure must be mastered. Bloomfield felt it necessary to use caps when he said, "LANGUAGE LEARNING IS OVERLEARNING; ANYTHING LESS IS OF NO USE." Passive reading of material which disguises the nature of the signals does not lead to mastery.

The active production of essential elements of structure through Prose Composition is a decided improvement over passive reading, but it too has serious flaws when viewed in the light of descriptive linguistics. For one thing, instead of demanding perfect control of one or two items at a time, it presents the student with a bewildering number of simultaneous problems. The laborious construction at home of five or ten sentences with grammar and dictionary is not a normal speech activity. Then again, the beginning student is not given

\footnotetext{
${ }^{1}$ Outline Guide for the Practical Study of Foreign Languages, Leonard Bloomfield (Baltimore, 1942) 12.
} 


\section{A SUBSTITUTE FOR PROSE COMPOSITION}

natural English to turn into Latin; the English sentences are predigested, written in a sort of metalanguage half way between English and Latin in order to suggest the forms that are expected. The student is taught that English of calls for a Latin genitive (except for because of, which is propter and the accusative), that to and for require a Latin dative (except for expressions like to the town, which is ad and the accusative), and so on, a series of one-to-one correspondences with their exceptions, all effectively concealing the essential differences between the language systems.

The recall of Latin words for their English equivalents is painfully slow, and both poor students and good habitually look up almost every word in an English-Latin dictionary. If the knowledge so laboriously acquired were useful, there might be little objection, but the very words for which they have learned a single English meaning will prove to be the chief stumbling blocks when they try to read a Latin author.

The principles of descriptive linguistics provide a guide for the creation of materials for beginning Latin classes. Such materials may have the following features: ${ }^{2}$

a) Selections from Latin authors arranged in a hierarchy of structure, beginning with single sentences and working up to continuous discourse.

b) Explanation of structure by constant contrast between English and Latin.

c) Memorization and overlearning of about 150 Latin quotations and mottoes.

d) Pattern Practices based on these quotations.

e) Oral-aural work, both in class and in the language laboratory.

f) Writing of original Latin sentences which imitate Latin selections which they already know.

This paper will concern itself with the last technique, which seems to be an effective substitute for Prose Composition.

The method has been tried and the results have been found interesting. After about two and a half months of Latin, the students of a University of Michigan class were asked to hand in fifty original sentences. Here is a sentence from each paper. Although this is not a random sampling, since only the better sentences are chosen, this selection gives a reasonably accurate picture of the papers as a whole:

2These features have been incorporated into mimeographed materials produced by the Department of Classical Studies at the University of Michigan. 
QuT caret saepe capit.

Laudem semper amat et nummum fēmina.

Ducunt volentem amorēs, nōlentem trahunt.

Ëbrietatem qut vincit hostem superat maximum.

Cógitur ad lacrimās fēmina dum vir cōgitur ad vīnum.

Ut. vêr dat florem, hiems stc reddit nivem.

QuT sua jactat indigne vivit.

QuT nōn habet pecūniam, litem habet atque dolōrem.

Nơn redit unda fluēns; nōn redit bona fortūna.

Ab oculō pūrō pūra dēfluit lacrima.

Canis vulpe sapientius est.

Exemplo melius quam verbō hominēs dūcuntur.

Fēmina laudem, vir rem vult.

Fêlicitās in oculó est, sed dolor in corde est.

QuT capit uxōrem, capit amōrem et fidem.

Saepius illae cadunt quae volunt fātum sublīme.

Quĩ prō uxōre dícit, satis est ēloquēns.

And one enterprising soul even essayed a poem as one of his fifty contributions:

\author{
Ut vēr dat flōrēs \\ et autumnus colōrēs, \\ sīc studium saepe honōrēs.
}

Not only do these sentences say something worthwhile, but they employ various rhetorical devices of word order.

Students may be shown how to write original sentences after two weeks of Latin. In this time, besides acquiring a general orientation to a structural approach to language study, they should have memorized about five Basic Sentences, such as the following:

Vestis virum facit.

Erasmus

Prūdēns cum cūrā vīvit, stultus sine cürā.

Medieval

Vulpēs vult fraudem, lupus agnum, fēmina laudem. Medieval

$\bar{A}$ cane nōn magnō saepe tenētur aper.

Ovid

$\bar{A}$ fonte pürō pūra dēfluit aqua. Anon.

and should have thoroughly studied about twenty-five Overlearns, such as:

Fūrem fūr cognōscit et lupum lupus.

Anon.

In pulchrā veste sapiēns nōn vĩvit honestē.

Medieval 


\section{A SUBSTITUTE FOR PROSE COMPOSITION}

Fortiter, fidēliter, fēlīciter.

Rem, nōn spem, quaerit amīcus.

Nemo in amōre videt.

Manus manum lavat.

Fidē et amōre.

Amor gignit amōrem.

Motto
Carmen de figuris

Propertius

Seneca

Motto

Injūria solvit amōrem.

Anon.

Vēritās numquam perit.

Anon.

Lîs lìtem generat.

Deus vult!

Seneca

Burton

Virtūte fidēque.

Battle Cry of First Crusade

Occāsiō facit fūrem.

Motto

Anon.

Vìtam regit fortūna, nōn sapientia.

Lūx et vēritās.

Cicero

Amphora sub veste numquam portātur honestē.

Motto of Yale

Antīquā veste pauper vestītur honestē.

Vincit vēritās.

Medieval

Medieval

Motto

Virtūte et labōre.

Motto

Nēmō sōlus satis sapit.

Dē sapientī virō facit Tra citō stultum.

Plautus

Tōtam hodiē Rōmam Circus capit.

Medieval

Lexx videt īrātum, ìrātus lēgem nōn videt.

Juvenal

Syrus

In omñ̄ rē vincit imitātiōnem vēritās.

Cicero

Such mottoes and quotations may be chosen on the following basis:

a) Content (student interest, illustration of Roman and medieval cultural traits, etc.)

b) Vocabulary (occurrence in later selections)

c) Structure (to this point, nominative, accusative, and ablative singular of the nouns and the third singular, active and passive, of the present tense of the verb).

The students are now shown how one may change any of these utterances by substitution, expansion, or transformalion in the following manner.

One may substitute for a word in a given form class any other word in that group that has the same corresponding form. That is, for a personal noun in the ablative one $m$ ay substitute any other personal noun in the ablative. Under certain conditions some substitutions across form classes is permitted. At this state the following form classes have been set up: ${ }^{3}$

3 Further subclasses must be set up later on. 


\section{LANGUAGE LEARNING}

\section{Declinable words}

$\begin{array}{lllll}\text { Personal nouns: } & & \text { vir lupus canis nēmō vulpēs } \\ \text { fưr agnus aper deus fémina }\end{array}$

Nonpersonal nouns: rēs cūra fidēs fraus injūria

lîs vīta manus labor vêritās

lūx fōns Rōma Circus fortūna

lex amor aqua vestis amphora

ìra spēs laus virtūs occāsīo

imitātiō sapientia

Transitive verbs: ${ }^{5}$ regit vincit lavat quaerit

tenet solvit capit cognōscit

portat gignit videt generat

Transitival verbs: ${ }^{6}$ facit vult

Intransitive verbs: ${ }^{7}$ vĩvit perit sapit dēfluit

$\begin{array}{llllll}\text { Adjectives: }^{8} & \text { pulcher } & \text { sapiēns } & \text { honestus } & \text { fortis } & \text { fidelis } \\ & \text { fê̄ix } & \text { prūdēns } & \text { magnus } & \text { pūrus } & \text { omnis } \\ & \text { sōlus } & \text { stultus } & \text { antĩquus } & \text { ĩrātus } & \text { tōtus } \\ & & & & & \text { citus }\end{array}$

$\begin{array}{lllll}\text { Adverbs: }^{9} & \begin{array}{l}\text { pulchrēe } \\ \text { stultēe }\end{array} & \begin{array}{l}\text { sapienter } \\ \text { fēliciter }\end{array} & \begin{array}{l}\text { fideliter } \\ \text { fortiter }\end{array} & \begin{array}{l}\text { honestē } \\ \text { prūdenter }\end{array}\end{array}$

4Identified now by meaning, later by formal characteristics: use as subject of first or second persons, use as vocative, use with $\bar{a} / a b$ and a passive verb to show agent.

5Identified by the contrast between the active ending $-t$ and the passive ending - tur. An accusative with this class of verb indicates Direct Object.

6Identified by listing here but formally by the lack of passive forms. An accusative with these verbs indicates Direct Object.

${ }^{7}$ Identified here by listing but formally by having no passive forms (except occasionally the third singular, the so-called impersonal use). An accusative with this class of verb is an adverbial modifier; this accusative will either pattern with a preposition, as in F/ümen ad mare défluil or if without a preposition will belong to a small list of words (mullum, nihil. Römam, etc.) Some of these intransitives are occasionally used as transitivals, but not in our corpus.

${ }^{8}$ Identified here by listing, but formally by having a contrast between masculine-feminine and neuter.

9Identified by the morphemes $-\bar{e}$ and $-t e r$ added to adjective bases. 


\section{A SUBSTITUTE FOR PROSE COMPOSITION}

$$
\text { Indeclinable words }{ }^{10}
$$

Adverbials: nōn numquam satis saepe hodiē

Conjunctions: et -que

Prepositions: in cum sine $\bar{a} / \mathbf{a b}$ sub

Taking as our model an Overlearn from page 11, Rem, $n \overline{o n}$ spem, quaerit amīcus ("A friend wants cash and not encouragement") we may substitute for rem any word in the nonpersonal class if we put it into the accusative case. (The students have been given the nominative, accusative, and ablative singular of each word when it first appeared.) If we take the first four words at random, we obtain the following:

Lîtem, nōn spem, quaerit amīcus.

Lucem, nōn spem, quaerit amícus.

Légem, nōn spem, quaerit amīcus.

Train, nōn spem, quaerit amīcus.

Since we did not select these words with regard for their lexical compatibility with the rest of the sentence, these originals are not particularly meaningful. When we try substitutions for the spem, we will consider the lexical meaning:

Rem, nōn laudem, quaerit amĩcus.

Rem, nōn injiriam, quaerit amīcus.

Rem, nōn sapientiain, quaerit amīcus.

Rem, nōn amôrem, quaerit amīcus.

In substituting for the verb, we choose from the same group as quaerit, that is from the transitives:

Rem, nōn spem, generat amīcus.

Finally, we may substitute for amicus, which is an adjective here used as a personal noun. ${ }^{11}$ We may choose from

${ }^{10}$ Identified by listing.

${ }^{11}$ We know that it is used as a noun because there is no noun for it to be in agreement with. We know that it is personal because it is masculine and not neuter. Some adjectives have a neuter form that is a nonpersonal noun (bonum, malum, etc.). 
either the list of the personal nouns or the list of adjectives:

Rem, nōn spem, quaerit fémina.

Rem, nōn spem, quaerit sapiēns.

We may substitute more than one element at a time:

Laudem, nōn lîtem, quaerit amīcus.

In fact, we may change them all (except the nön):

Vestem, nōn amphoram, lavat fēmina.

Expansion involves the addition or subtraction of items. At this stage the students can add (or subtract) adverbs, adverbials, ablatives, or any words in series. By addition:

Rem, nōn spem, saepe quaerit amīcus.

And by subtraction:

Rem quaerit amicus.

Transformation involves a change in syntax. At this point the students understand only the change from active to passive and the reverse:

Rēs, nōn spēs, quaeritur ab amīcō.

By combining these three processes of substitution, expansion, and transformation (and changing the word order, if necessary) we can change any utterance into any other utterance. Here is how one might change Injüria solvit amōrem into Véritās numquam perit:

Injūria solvit amōrem.

Injūriā solvitur amor.

(transformation)

Solvitur amor.

Perit amor.

(expansion)

(substitution) 12

${ }^{12} \mathrm{~A}$ passive verb (without the type of ablative modifier traditionally called Means and Agent) is interchangeable with an intransitive verb. 


\section{A SUBSTITUTE FOR PROSE COMPOSITION}

Perit vēritās.

Perit numquam vēritās.

Vēritās numquam perit. (substitution)

(expansion)

(change of word order)

As a first assignment in original sentence writing, a class may be given the following instructions:

"Write twenty-five original sentences, using the techniques as indicated:

a. Five sentences where one word has been substituted.

b. Five sentences where two words have been substituted.

c. Five sentences where three words have been substituted.

d. Five sentences where you use only expansion.

e. Five sentences where you use transformation without expansion or substitution."

Here is one correct sentence from each paper that was handed in by a class which had had eight lessons in Latin. To see if the description was adequate, the only explanation given them was that in their text, essentially as it has been presented above. 13

Vir in amōre videt.

Manus lavat amphoram.

Fortūnā vìta regitur, nōn sapientiā.

Rem, nōn lītem, quaerit fūr.

$\bar{A}$ fūre fūr cognōscitur et $\bar{a}$ lupō lupus.

Fidess numquam perit.

Amōre amor gignitur.

Virō honestō pūra dēfluit vēritās.

Fēmina injūriam cognōscit.

Stultus tenet numquam rem, numquam amōrem.

Vestis fēminam facit.

Amor saepe perit.

Vitam capit labor.

Vir vult amōrem, lupus agnum, fēmina rem.

13 It should be noted that two students were unable to do this assignment at all. While it is possible that proper explanation in class before they were asked to do the assignment might have improved their performance, it is my opinion that emotional disturbance rather than lack of understanding was involved. One student, who had had two years of high school Latin but was repeating, dropped the course within a few days. The other student finished the semester far behind everyone else. 


\section{LANGUAGE LEARNING}

Vincit fortūna.

Fūrem îrātus cognōscit.

Injūriā solvitur amor.

Vestis et fortūna virum facit.

Rēs, nōn spēs, quaeritur ab amīcō.

Prūdēns cum cūrā vīvit.

Vestis pulchra virum facit.

In antîquā veste vir nōn vivit fortiter.

When the students reach connected discourse, they can be required to paraphrase a passage in Latin, making at least one change in each sentence.

This type of exercise would seem to have the following advantages over the traditional Prose Composition:

a. It gives the student a sense of achievement. He has expressed his own thoughts in a foreign language.

b. The emphasis is upon producing whole utterances rather than putting pieces together.

c. There is little vocabulary burden; the student uses the words which he knows.

d. Errors are few.

e. The student learns something about the rhetorical uses of word order.

f. Reference is to a Latin model, not an English one, and the activity is carried on largely in Latin. 